\title{
Identifikasi Kromosom Ikan Nila (Oreochromis niloticus) Strain Merah Jatimbulan dan Larasati yang Diambil dari Lokasi Berbeda
}

\section{Identification Chromosome Red Tilapia (Oreochromis niloticus) Strains Jatimbulan and Larasati Taken from Different Locations.}

\author{
Syifa Fauziah $^{1}$, Laksmi Sulmartiwi $^{2^{*}}$, dan Widjiati ${ }^{3}$ \\ ${ }^{1}$ Departemem Manajemen Kesehatan Ikan dan Budidaya Perairan, Fakultas Perikanan dan Kelautan, Universitas \\ Airlangga, Surabaya, Indonesia \\ 2 Departemem Kelautan, Fakultas Perikanan dan Kelautan, Universitas Airlangga, Surabaya, Indonesia \\ ${ }^{3}$ Departemen Anatomi veteriner, Fakultas Kedokteran Hewan, Universitas Airlangga, Surabaya, Indonesia
}

Koresponding: Laksmi Sulmartiwi, Departemen Kelautan, Fakultas Perikanan dan Kelautan, Universitas Airlangga, Surabaya, Indonesia

E-mail: laksmi-s@fpk.unair.ac.id

\begin{abstract}
Abstrak
Ikan nila merah Jatimbulan dan ikan nila Larasati merupakan hasil rekayasa genetik dari dua lokasi yang berbeda. Ikan yang berasal dari lokasi yang berbeda mempunyai karakter yang berbeda karena adanya pengaruh interaksi antara genetik dan lingkungannya. Lingkungan merupakan salah satu faktor pembatas dari tiap populasi ikan dari segi morfometrik ataupun genetik. Perbedaan suhu, cahaya, nutrisi dan faktor lingkungan lain memiliki dampak perbedaan kromosom pada setiap strain ikan. Dalam upaya mendapatkan informasi mengenai hal tersebut, maka penelitian ini akan membahas bagaimana gambaran kromosom dari dua strain ikan nila merah yang dibudidayakan di lokasi yang berbeda. Penelitian ini bertujuan untuk mengetahui gambaran kromosom (jumlah kromosom, bentuk kromosom dan susunan kromosom) ikan nila merah Jatimbulan dan ikan nila Larasati. Hasil dari penelitian ini menunjukkan jumlah kromosom ikan nila merah Jatimbulan dan ikan Larasati adalah 44 pasang $(2 n=44)$. Bentuk dan susunan kromosom (karyotipe) ikan nila merah Jatimbulan adalah 4 pasang sub metasentrik, 9 pasang sub telosentrik dan 9 pasang telosentrik (4SM-9ST-9T), sedangkan kromosom dari ikan nila Larasati adalah 3 pasang sub metasentrik, 14 pasang sub telosentrik dan 5 pasang telosentrik (3SM- 14ST-5T).
\end{abstract}

Kata kunci: Identifikasi, Kromosom, Ikan Nila, Strain Merah Jatimbulan, dan Strain Merah Larasati

\begin{abstract}
Red tilapia fish strains Jatimbulan and Larasati is the result of genetic engineering from two different locations. Fish originating from different locations have different characters because of the influence of the interaction between genetics and the environment. The environment is one of the limiting factors of each of the fish populations in terms of morfometrik or genetic. The difference in temperature, light, nutrients and other environmental factors having an impact on every chromosome difference fish strains. In an attempt to get information about it, then this research will explore how the image of the chromosome from two strains of Red tilapia fish cultivated in different locations. This research aims to know the description of the chromosome (chromosome number, the shape of chromosomes and chromosomal) red tilapia fish Jatimbulan and Larasati. The results of this research is the number of chromosome of red tilapia fish Jatimbulan and Larasati was 44 pairs $(2 n=44)$. The shape and arrangement of the chromosomes (karyotipe) red tilapia strain Jatimbulan are 4 pairs of sub 9 plug the sub metasentrik telosentrik and 9 pairs of telosentrik (4SM-9ST-9T), whereas chromosome of red tilapia strain Larasati was 3 pairs of sub metasentrik sub telosentrik pairs, 14 and 5 pairs of telosentrik (3SM-14ST-5T).
\end{abstract}

Keywords: Identification, chromosome, Indigo fish, Jatimbulan red Strain, and red Strain of Larasati 


\section{Pendahuluan}

Usaha perbaikan strain ikan bertujuan untuk mendapatkan genotipe ikan yang mempunyai tingkat produktivitas tinggi pada kegiatan budidaya. Produktivitas tinggi dapat dicapai apabila strain ikan yang digunakan mempunyai kualitas genetik dan penampilan fenotipik yang baik. Secara umum, penampilan fenotipik suatu organisme ditentukan oleh faktor internal (genetik) dan dipengaruhi oleh faktor eksternal (lingkungan) (Ariyanto dan Listiyowati, 2015).

Genetik dan lingkungan merupakan faktor penting yang dapat mempengaruhi terbentuknya fenotip. Fenotip adalah sifat yang tampak dari luar dan dapat diamati morfologi, fisiologi dan tingkah lakunya. Fenotip merupakan hasil interaksi antara lingkungan dengan faktor genotip. Ikan nila merupakan salah satu komoditas penting perikanan budidaya air tawar di Indonesia. Dalam rangka peningkatan produktivitas budidaya ikan nila (Oreochromis niloticus), beberapa strain unggul hasil pemuliaan telah dihasilkan dan secara resmi dilepas ke masyarakat untuk dibudidayakan. Strain unggul tersebut antara lain ikan nila merah Jatimbulan dan ikan nila Larasati.

Ikan nila merah Jatimbulan merupakan hasil pemuliaan ikan Unit Pelaksana Teknis Pengembangan Budidaya Air Tawar (UPT PBAT) Umbulan yang dilakukan dengan cara seleksi individu menggunakan enam strain induk nila yang kemudian saling menyilang dan dipijahkan (Dinas Kelautan dan Perikanan Propinsi Jawa Timur-Balai Pengembangan Budidaya Air Tawar Umbulan, 2016). Berdasarkan Keputusan Menteri Kelautan dan Perikanan Republik Indonesia No. Kep. 11/Men/2008, ikan nila Jatimbulan telah ditetapkan sebagai galur unggul induk ikan nila Jatimbulan.

Ikan nila Larasati adalah ikan nila merah hasil pemuliaan ikan di Satuan Kerja Pembenihan dan Budidaya Ikan Air Tawar (Satker PBIAT) Janti yang dihasilkan dari persilangan ikan nila Gift dan ikan nila
Singapura. Berdasarkan Keputusan Menteri Kelautan dan Perikanan Republik Indonesia No. Kep. 79/Men/2009, ikan nila Larasati telah ditetapkan sebagai benih bermutu.

Ikan nila merah Jatimbulan dan ikan nila Larasati merupakan hasil rekayasa genetik dari dua lokasi yang berbeda. Ikan yang berasal dari lokasi yang berbeda mempunyai karakter yang berbeda karena adanya pengaruh interaksi antara genetik dan lingkungannya (Dunham, 2004). Lingkungan merupakan salah satu faktor pembatas dari tiap populasi ikan dari segi morfometrik ataupun genetik (Saputra et al., 2014). Karakter genetik diturunkan dari induk ke keturunannya melalui kromosom yang mengandung informasi genetik, jumlah kromosom yang diturunkan antara induk dan keturunannya selalu sama.

Penelitian mengenai pengaruh lingkungan terhadap kromosom pernah dilakukan pada ikan nilem (Osteochilus sp.) oleh Nuryanto (2001) dari kolam dan sungai Cikawung, Cilacap yang hasilnya jumlah kromosom ikan nilem sungai Cikawung $2 n=48$ dan ikan nilem kolam sebanyak $2 n=46$. Penelitian Defira (2004) pada ikan lalawak (Barbodes balleroides) dan lalawak jengkol (Barbodes sp.) dari sungai Cikandungan dan kolam budidaya di Sumedang didapatkan hasil ikan lalawak dan lalawak jengkol dengan jumlah kromosom sama, yaitu $2 \mathrm{n}=48$. Serta penelitian yang dilakukan Andriani et al. (2004) mengenai kariotip ikan hias endemik rainbow Sulawesi dari tiga lingkungan anak sungai menyatakan bahwa jumlah kromosom ikan rainbow yaitu $2 n=48$, terdapat perbedaan pada bentuk dan susunan kromosom.

Berdasarkan penelitian tersebut dapat menjadi acuan untuk dilakukan penelitian identifikasi kromosom ikan nila yang diambil dari lokasi (lingkungan) berbeda. Penelitian ini menggunakan ikan nila unggul yaitu ikan nila strain merah Jatimbulan dari Pasuruan dan ikan nila Larasati dari Klaten. Variasi genetik diduga disebabkan karena adanya perbedaan kondisi geografis, 
agroklimatologis dan teknologi budidaya yang dikembangkan antar lokasi. Perbedaan suhu, cahaya, nutrisi dan faktor lingkungan lain memiliki dampak perbedaan kromosom pada setiap strain ikan. Dalam upaya mendapatkan informasi mengenai hal tersebut, maka penelitian ini akan membahas bagaimana gambaran kromosom dari dua strain ikan nila merah yang dibudidayakan di lokasi yang berbeda.

\section{Material dan Metode}

\section{Material}

Bahan-bahan yang digunakan dalam penelitian ini antara lain benih ikan nila merah Jatimbulan dan ikan nila Larasati ukuran 3-5 cm, kolkisin (C22H25NO6), $\mathrm{KCL}$, etanol $\left(\mathrm{C}_{2} \mathrm{H}_{5} \mathrm{OH}\right)$, asam asetat glacial $(\mathrm{CH} 3 \mathrm{COOH})$, giemsa, akuades, oil emersi.

\section{Metode}

Metode penelitian yang digunakan dalam penelitian ini adalah deskriptif. Pada penelitian dibuat deskripsi tentang gambaran kromosom ikan nila merah Jatimbulan dan ikan nila Larasati.

\section{Prosedur Penelitian}

Persiapan penelitian meliputi persiapan laboratorium, sterilisasi alat dan aklimatisasi ikan, kemudian dilanjutkan dengan pengukuran berat dan panjang ikan. Ikan yang akan diteliti sebanyak 5 ekor dari masing-masing strain.

Prosedur yang pertama adalah 5 ekor benih ikan nila merah Jatimbulan dilakukan perendaman dengan kolkisin 0,007\% (dengan cara melarutkan $7 \mathrm{mg}$ kolkisin dalam 1L air) selama 6-7 jam pada akuarium yang sudah dilengkapi dengan aerator. Perendaman kolkisin juga dilakukan pada ikan nila Larasati dan diletakkan pada akuarium yang berbeda dari ikan nila merah Jatimbulan kemudian dilanjutkan memotong dan mengambil insang pada masing-masing ikan.

Insang yang sudah diambil selanjutnya direndam dalam larutan hipotonik $(\mathrm{KCl}$ $0,075 \mathrm{M})$ selama 60 menit. Selama perendaman dilakukan pergantian larutan hipotonik setiap 30 menit dengan volume 20 kali volume insang. Larutan hipotonik 0.075 $\mathrm{M}$ dibuat dengan melarutkan 0,56 gram KCL dalam $100 \mathrm{ml}$ akuades. Perendaman KCL pada insang ikan nila merah Jatimbulan dan Larasati dilakukan pada beaker glass yang berbeda agar jaringan tidak tercampur. Perlakuan hipotonik bertujuan agar sel-sel membesar dan kromosom-kromosom menyebar letaknya.

Fiksasi dilakukan setelah jaringan direndam dengan larutan hipotonik, kemudian dilanjutkan dengan perendaman ke dalam larutan fiksatif (larutan Carnoy) selama 60 menit (2x30 menit). Larutan Carnoy dibuat dengan cara mencampurkan asam asetat glasial dan etanol (perbandingan 1:3) (Siagian, 2006), kemudian dilanjutkan dengan pembuatan preparat langsung atau bila diperlukan jaringan yang telah difiksasi tadi dapat disimpan dalam refrigerator selama 2-3 minggu.

Insang yang telah difiksasi diambil
dengan menggunakan pinset dan disentuhkan pada kertas tisu untuk menghilangkan larutan fiksatif. Object glass direndam dalam larutan alkohol 70\% selama lebih kurang 2 jam dahulu sebelum digunakan. Jaringan insang kemudian diletakkan di object glass cekung dan ditambahkan 3-4 asam asetat 50\%, selanjutnya jaringan dicacah secara perlahan-lahan sehingga terbentuk suspensi yang ditandai dengan larutan menjadi keruh. Suspensi kemudian diambil menggunakan pipet tetes secara perlahan agar tidak membentuk gelembung udara. Suspensi tersebut kemudian diteteskan di atas object glass yang diletakkan di atas hot plate dengan suhu $45-50^{\circ} \mathrm{C}$ selanjutnya diambil kembali setelah terbentuk lingkaran (ring) berdiameter 1-1,5 cm dan dikeringudarakan pada suhu ruang sebelum dilakukan pewarnaan preparat.

Pada proses pewarnaan preparat, preparat diwarnai dengan larutan giemsa $20 \%$, yaitu mencampurkan giemsa dan akuades dengan perbandingan 2:8 
sebanyak 1-2 tetes, kemudian diratakan hingga menutupi ring dengan menggunakan tusuk gigi. Preparat kemudian disimpan selama 20-30 menit pada suhu ruangan dan selanjutnya dibilas dengan akuades dan dibiarkan mengering. Preparat yang telah kering dilakukan pengamatan di bawah mikroskop dengan perbesaran 100, 400 dan 1000 kali dengan menggunakan oil emersi untuk dihitung jumlah kromosom serta diamati bentuk dan ukurannya.

Pada pengamatan preparat yang menghasilkan sebaran kromosom yang baik dan jumlahnya lengkap kemudian difoto, kemudian hasil tersebut dapat digunakan dalam penyusunan karyotipe untuk masingmasing strain ikan nila. Jumlah kromosom dihitung dan diambil dari sebaran yang baik. Kromosom diploid dengan frekuensi tertinggi (modus) diurutkan dan dipasangkan berdasarkan pada ukuran dan bentuknya. Variabel yang diukur pada penelitian ini antara lain adalah panjang kromosom, panjang lengan (pendek dan panjang) sedangkan variabel yang dihitung yaitu Numeric value centromer (NVC) atau harga numerik sentromer (HNPS) (Levan et al., 1964; McGregor and Varley, 1983). Perhitungan Numeric value centromer (NVC) dapat menggunakan rumus sebagai berikut :

$$
\text { NVC }=\frac{\text { Panjang lengan pendek }}{\text { Panjang kromosom total }}
$$

Penentuan tipe kromosom berdasarkan nilai selang indeks sentromer dapat dilihat pada Tabel 1. Indeks sentromer adalah rasio dari lengan yang lebih pendek dengan panjang total kromosom (McGregor and Varley, 1983).

\section{Analisis Data}

Data yang didapatkan dari pengamatan kromosom dibahas secara deskriptif, kemudian digunakan untuk menjawab rumusan masalah penelitian. Diagram alir penelitian dapat dilihat pada, analisa data secara deskriptif yang disajikan dalam bentuk tabel dan gambar.

\begin{tabular}{|c|c|c|c|}
\hline $\begin{array}{l}\text { Posisi } \\
\text { Sentromer }\end{array}$ & $\begin{array}{l}\text { Terminologi } \\
\text { Alternatif }\end{array}$ & Simbol & $\begin{array}{l}\text { Selang } \\
\text { Indeks } \\
\text { Sentromer } \\
\text { (\%) }\end{array}$ \\
\hline Median & Metasentrik & $M$ & $\begin{array}{l}46- \\
49\end{array}$ \\
\hline Sub-Median & $\begin{array}{l}\text { Sub } \\
\text { metasentrik } \\
\text { (Lebih } \\
\text { metasentrik) }\end{array}$ & SM & $\begin{array}{l}36- \\
45\end{array}$ \\
\hline Sub-Median & $\begin{array}{l}\text { Sub } \\
\text { metasentrik } \\
\text { (Kurang } \\
\text { metasentrik) }\end{array}$ & SM & $\begin{array}{l}26- \\
35\end{array}$ \\
\hline Sub-Terminal & Akrosentrik & ST & $\begin{array}{l}16- \\
25\end{array}$ \\
\hline Sub-Terminal & Akrosentrik & $\mathrm{T}$ & $>15$ \\
\hline
\end{tabular}

Tabel 1. Klasifikasi kromosom berdasarkan posisi sentromer (McGregor and Valley 1983) 
Tabel 2. Jumlah kromosom ikan nila merah jatimbulan dan larasati

\begin{tabular}{cl} 
No. & Strain Ikan \\
\hline 1. & Ikan nila merah Jatimbulan \\
2. & Ikan nila Larasati \\
\hline
\end{tabular}

\section{Hasil dan Pembahasan}

Jumlah, Bentuk dan Susunan Kromosom

Berdasarkan hasil pengamatan dan pengukuran kromosom didapatkan hasil bahwa terdapat persamaan dan perbedaan dari ikan nila merah Jatimbulan dan ikan nila Larasati. Sebaran kromosom ikan nila merah Jatimbulan dan Larasati dapat dilihat pada Gambar 1 dan Gambar 12. Hasil penghitungan dari sebaran kromosom menunjukkan bahwa terdapat persamaan jumlah kromosom diploid dari ikan nila merah Jatimbulan dan ikan nila Larasati yaitu $2 n=44$ (Tabel 2 ).

Ukuran dan bentuk kromosom ikan nila merah Jatimbulan dan Larasati yang diamati cukup bervariasi. Ukuran panjang kromosom ikan nila merah Jatimbulan antara 5,8 $\mu \mathrm{m}-1,9 \mu \mathrm{m}$, sedangkan ukuran panjang kromosom ikan nila Larasati antara
6,1 $\mu \mathrm{m}-1,1 \mu \mathrm{m}$. Dari data ukuran panjang setiap pasang kromosom disusun karyotipe berdasarkan ukuran kromosom mulai dari terpanjang sampai yang terpendek. Hasil penyusunan karyotipe dari ikan nila merah Jatimbulan menunjukkan terdapat 4 pasang sub metasentrik (no. 1, 2, 3, 5); 9 pasang sub telosentrik (no. 4, 6, 7, 8, 9, 11, 14, 15, 16) dan 9 pasang telosentrik (no. 10, 12, 13, 17, 18, 19, 20, 21, 22). Bentuk dari ikan nila Larasati terdapat 3 pasang sub metasentrik $(2,3,6) ; 14$ pasang sub telosentrik $(1,4,5,7,8,9,10,11,12,13,14$, $15,16,20$ ) dan 5 pasang telosentrik (no. 17, $18,19,21,22)$. Ukuran, bentuk dan susunan kromosom ikan nila merah Jatimbulan dan ikan nila Larasati terdapat pada Tabel 3 dan Tabel 4.

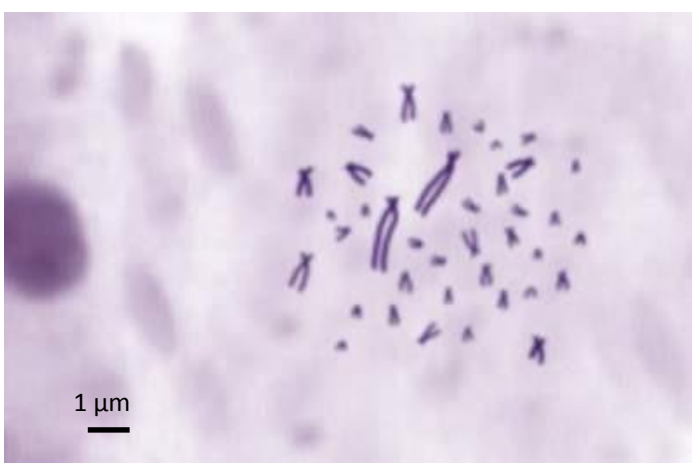

Gambar 1. Sebaran Kromosom Ikan Nila Merah Jatimbulan (Mikroskop perbesaran 1000x kemudian diperbesar dengan software photoshop) 


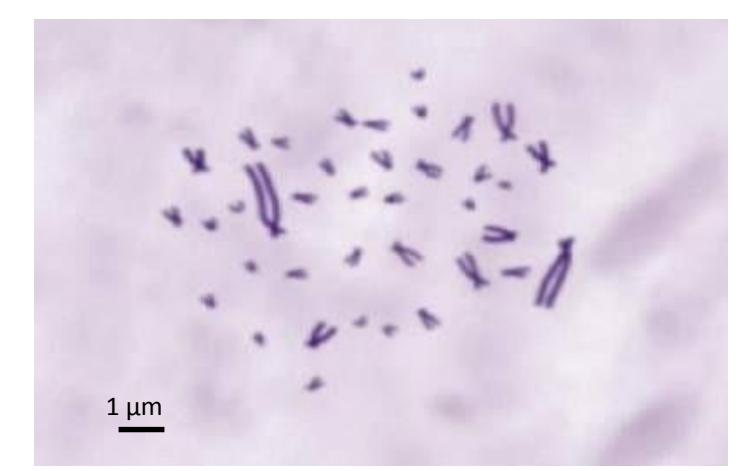

Gambar 2. Sebaran Kromosom Ikan Nila Larasati

\section{Morfometrik Meristik}

Pengamatan dan pengukuran morfometrik meristik ikan nila merah Jatimbulan dan ikan nila Larasati dilakukan pada awal penelitian. Hasil morfometrik meristik ikan nila merah Jatimbulan dan ikan nila Larasati dapat dilihat pada Tabel 5.

Berdasarkan hasil identifikasi kromosom pada ikan nila merah Jatimbulan dan ikan nila Larasati yang diambil dari lokasi berbeda memperlihatkan adanya persamaan pada jumlah kromosom dan perbedaan yang bervariasi dari segi bentuk, susunan maupun kisaran panjang relatifnya.

Pengamatan kromosom dilakukan secara baik, hal ini dikarenakan kromosom dapat dihitung jumlahnya. Sebaran kromosom yang relatif baik adalah kromosom yang dapat diamati jumlah dan bentuk kromosom (Hartono, 2003).

Jumlah kromosom ikan nila merah Jatimbulan dan ikan nila Larasati sebanyak $2 n=44$. Hal ini sesuai dengan penelitian yang dilakukan Sofy et al. (2008) tentang karyotipe dari tiga spesies ikan nila menunjukkan bahwa jumlah kromosom ketiga spesies ikan nila adalah $2 n=44$. Menurut Siagian (2006), jumlah kromosom di dalam sel tubuh secara normal terdapat dua set kromosom, satu set berasal dari telur dan satu set lagi berasal dari sperma sehingga sering digambarkan sebagai diploid (2n). Jumlah kromosom suatu spesies memiliki kemungkinan sama, tetapi kromosom satu dengan kromosom lainnnya berbeda bentuk, ukuran dan komposisi gen dengan kromosom lainnya (Saputra et al., 2014). Bentuk kromosom ikan nila merah Jatimbulan menunjukkan terdapat 4 pasang sub metasentrik, 9 pasang sub telosentrik dan 9 pasang telosentrik. Bentuk kromosom dari ikan nila Larasati terdapat 3 pasang sub metasentrik, 14 pasang sub telosentrik dan 5 pasang telosentrik. Bentuk kromosom menunjukkan perbedaan yang bervariasi antara ikan nila merah Jatimbulan dan ikan nila Larasati. Penyusunan kromosom ikan nila ditata secara urut dari kromosom terpanjang sampai dengan kromosom terpendek. Panjang kromosom ikan nila merah Jatimbulan dan ikan nila Larasati cukup bervariasi. ikan nila Larasati mempunyai panjang kromosom yang sedikit lebih panjang dibandingkan dengan ikan nila merah Jatimbulan. Ukuran panjang kromosom ikan nila merah Jatimbulan antara 5,8 $\mu \mathrm{m}-1,9 \mu \mathrm{m}$, sedangkan ukuran panjang kromosom ikan nila Larasati antara 6,1 $\mu \mathrm{m}-1,1 \mu \mathrm{m}$. Perbedaan ukuran kromosom kemungkinan disebabkan oeh perbedaan pada saat terjadinya pembelahan mitosis (Siagian, 2006). Hal ini didukung oleh pendapat Moyniham and Mahon (1982) yang menyebutkan bahwa ada perubahan antara panjang kromosom dan volume kromosom selama mitosis. 
Tabel 3. Ukuran, bentuk dan susunan kromosom ikan nila merah Jatimbulan

\begin{tabular}{|c|c|c|c|c|c|}
\hline No. & Kromosom & $\begin{array}{l}\text { Lengan } \\
\text { Pendek }(\mu \mathrm{m})\end{array}$ & $\begin{array}{l}\text { Panjang } \\
\text { Kromoso } \\
\mathrm{m}(\mu \mathrm{m})\end{array}$ & $\begin{array}{l}\text { NVC } \\
(\%)\end{array}$ & $\begin{array}{l}\text { Tipe } \\
\text { Kromosom }\end{array}$ \\
\hline 1 & 11 & 1,5837 & 5,8325 & 27,15 & SM \\
\hline 2 & $x X$ & 1,7477 & 4,2786 & 40,84 & SM \\
\hline 3 & $x x$ & 1,5804 & 3,9667 & 39,84 & SM \\
\hline 4 & $x$ & 0,7531 & 3,8567 & 19,52 & ST \\
\hline 5 & $x x$ & 1,7056 & 3,8000 & 44,88 & SM \\
\hline 6 & $x$ & 0,9132 & 3,7783 & 24,16 & ST \\
\hline 7 & X & 0,8657 & 3,6116 & 23,96 & ST \\
\hline 8 & $1 x$ & 0,7990 & 3,4589 & 23,09 & ST \\
\hline 9 & $\Delta x$ & 0,6423 & 3,3600 & 19,11 & ST \\
\hline 10 & גו & 0,4238 & 3,3512 & 12,64 & $\mathrm{~T}$ \\
\hline 11 & $x x$ & 0,6157 & 3,2997 & 18,65 & ST \\
\hline 12 & AA & 0,0000 & 3,2167 & 00,00 & $\mathrm{~T}$ \\
\hline 13 & $x x$ & 0,3839 & 3,1986 & 12,00 & $\mathrm{~T}$ \\
\hline 14 & $x$ & 0,5643 & 3,1899 & 17,69 & ST \\
\hline 15 & $\lambda x$ & 0,6076 & 3.1498 & 19,29 & ST \\
\hline 16 & $x$ & 0,5252 & 3,1200 & 16,83 & ST \\
\hline 17 & $x a$ & 0,1798 & 2,9340 & 6,12 & $\mathrm{~T}$ \\
\hline 18 & $A \cap$ & 0,0000 & 2,6329 & 0,00 & $\mathrm{~T}$ \\
\hline 19 & $n n$ & 0,0000 & 2,3121 & 0,00 & $\mathrm{~T}$ \\
\hline 20 & $A \wedge$ & 0,0000 & 2,2672 & 0,00 & $\mathrm{~T}$ \\
\hline 21 & An & 0,0000 & 2,1043 & 0,00 & $\mathrm{~T}$ \\
\hline 22 & $\wedge$ & 0,0000 & 1,9854 & 0,00 & $\mathrm{~T}$ \\
\hline
\end{tabular}


Tabel 4. Ukuran, bentuk dan susunan kromosom ikan nila larasati

\begin{tabular}{|c|c|c|c|c|c|}
\hline No. & Kromosom & $\begin{array}{l}\text { Lengan } \\
\text { Pendek } \\
(\mu \mathrm{m})\end{array}$ & $\begin{array}{l}\text { Panjang } \\
\text { Kromosom } \\
(\mu \mathrm{m})\end{array}$ & $\begin{array}{l}\text { NVC } \\
(\%)\end{array}$ & $\begin{array}{c}\text { Tipe } \\
\text { Kromosom }\end{array}$ \\
\hline 1 & $x y$ & 1,4234 & 6,1475 & 23,15 & ST \\
\hline 2 & $x x$ & 1,8961 & 5,7339 & 33,06 & SM \\
\hline 3 & $x x$ & 1,8065 & 5,4756 & 32,99 & SM \\
\hline 4 & חג & 1,2911 & 5,4689 & 23,60 & ST \\
\hline 5 & $x \Lambda$ & 1,3756 & 4,9897 & 21,71 & ST \\
\hline 6 & $x x$ & 2,0007 & 4,7987 & 41,69 & SM \\
\hline 7 & 11 & 1,0543 & 4,6465 & 22,69 & ST \\
\hline 8 & $x$ & 1,0040 & 4,5643 & 21,99 & ST \\
\hline 9 & $\Lambda x$ & 0,9879 & 4,4327 & 22,28 & ST \\
\hline 10 & $\pi x$ & 0,7787 & 3,7654 & 20,68 & ST \\
\hline 11 & $x x$ & 0,6983 & 3,3124 & 21,08 & ST \\
\hline 12 & $x x$ & 0,5812 & 2,8078 & 20,69 & ST \\
\hline 13 & $x \pi$ & 0,4006 & 2,5087 & 15,96 & ST \\
\hline 14 & $x x$ & 0,4268 & 2,4801 & 17,20 & ST \\
\hline 15 & $\lambda x$ & 0,5010 & 2,3939 & 20,92 & ST \\
\hline 16 & $x x$ & 0,4118 & 2,1829 & 18,86 & ST \\
\hline 17 & $x a$ & 0,1362 & 1,8834 & 7,23 & T \\
\hline 18 & An & 0,0000 & 1,5490 & 00,00 & $\mathrm{~T}$ \\
\hline 19 & $1 n$ & 0,0000 & 1,4849 & 00.00 & $\mathrm{~T}$ \\
\hline 20 & As & 0,3010 & 1,4700 & 20,47 & ST \\
\hline 21 & nn & 0,0000 & 1,2825 & 00,00 & $T$ \\
\hline 22 & $\wedge$ & 0,0000 & 1,1210 & 00,00 & $\mathrm{~T}$ \\
\hline
\end{tabular}

Keterangan

SM $\mathrm{T}$

: Sub Metasentrik ST

: Sub Telosentrik 
Tabel 5. Morfometrik meristik ikan nila merah Jatimbulan dan ikan nila Larasati

\begin{tabular}{ccccccc}
\hline No. Strain ikan & $\begin{array}{c}\text { Panjang } \\
\text { total } \\
(\mathrm{cm})\end{array}$ & $\begin{array}{l}\text { Panjang } \\
\text { standart } \\
(\mathrm{cm})\end{array}$ & $\begin{array}{l}\text { Tinggi } \\
\text { badan } \\
(\mathrm{cm})\end{array}$ & $\begin{array}{l}\text { Tinggi } \\
\text { kepala } \\
(\mathrm{cm})\end{array}$ & Warna \\
\hline 1 & $\begin{array}{c}\text { Ikan nila merah } \\
\text { Jatimbulan }\end{array}$ & 4,5 & 3,5 & 1,8 & 1,3 & Merah \\
2 & Ikan nila Larasati & 3,8 & 3 & 1,4 & 1 & $\begin{array}{c}\text { Merah } \\
\text { agak } \\
\text { orange }\end{array}$ \\
\hline
\end{tabular}

Perbedaan karyotipe dan susunan kromosom diduga merupakan pengaruh adaptasi ikan terhadap lingkungan yang berbeda. Lokasi pengambilan ikan nila terletak di dua tempat yang memiliki kondisi geografis dan sumber air yang berbeda. Perbedaan lokasi dan kondisi geografis habitat suatu spesies merupakan salah satu komponen penting yang dapat mengubah genetik. Menurut Hartono (2003) perbedaan karyotipe dapat disebabkan karena lingkungan yang berbeda. Proses perubahan kromosom dapat disebabkan oleh pengaruh lingkungan (fisika dan kimia) sehingga proses pembelahan sel meiosis dan mitosis akan terganggu dan tidak berjalan dengan semestinya sehingga mengakibatkan adanya perubahan komposisi gen dari satu kromosom dibanding dengan induknya.

Perubahan material genetik dapat disebabkan oleh proses spontan maupun adanya rangsangan dari luar. Perubahan secara spontan terjadi akibat kesalahan acak yang berlangsung dalam proses replikasi atau saat terjadinya pembentukan sel. Sedangkan rangsangan dari luar yang mempengaruhi dapat berupa bahan kimia, faktor fisik dan biologi.

Perbedaan karyotipe ikan juga dapat disebabkan oleh perlakuan selama pembuatan preparat seperti perlakuan perendaman kolkisin serta preparasi di atas slide. mengemukakan bahwa perlakuan terhadap ikan dalam preparasi kromosom tidak selalu menghasilkan kontraksi sel serta sebaran kromosom yang tepat pada saat metafase. Hal ini dikarenakan adanya respon individu yang berbeda terhadap perlakuan kolkisin. Selain itu, waktu perendaman sangat bergantung pada suhu dan konsisten jaringan yang digunakan (Hartono, 2003).

Berdasarkan hasil pengamatan morfometrik meristik ikan nila merah Jatimbulan dan ikan nila Larasati, dapat disimpulkan adanya perbedaan morfologi yang bervariasi. Morfometrik meristik merupakan salah satu cara untuk mengetahui keanekaragaman dari suatu spesies dengan melakukan pengujian terhadap karakter morfologi secara umum. Data morfometrik meristik dapat digunakan untuk menjelaskan perbedaan dan persamaan antar populasi. Perbedaan morfologi ikan dipengaruhi oleh banyak faktor, salah satunya yaitu faktor lingkungan. Faktor lingkungan selain banyak berpengaruh pada fisiologi ikan juga dapat mempengaruhi adanya variasi morfologi ikan. Variasi morfologi ikan dapat terjadi pada individu satu spesies yang hidup di lingkungan berbeda (Nuryanto, 2001). Menurut Ehlinger (1991) variasi bentuk dan ukuran pada ikan dapat dihasilkan oleh pengaruh lingkungan, terutama arus air.

\section{Kesimpulan}

Simpulan dari penelitian ini adalah jumlah kromosom ikan nila merah Jatimbulan dan ikan Larasati adalah 44 pasang $(2 n=44)$. Bentuk dan susunan kromosom (karyotipe) ikan nila merah Jatimbulan adalah 4 pasang sub metasentrik, 9 pasang sub telosentrik dan 9 pasang telosentrik (4SM-9ST-9T), 
sedangkan kromosom dari ikan nila Larasati adalah 3 pasang sub metasentrik, 14 pasang sub telosentrik dan 5 pasang telosentrik (3SM-14ST-5T).

\section{Daftar Pustaka}

Andriani, I., Sugiri, N., Carman, O., \& Sjafei, D.S. (2004). Kariotip ikan hias endemik rainbow Sulawesi (Telmatherina ladigesi) dari Sungai Maros, Sulawesi Selatan. Jurnal Akuakultur Indonesia, 3(2):13-18.

Ariyanto, D. \& Listiyowati, N. (2015). Interaksi genotipe dengan lingkungan, adaptabilitas dan stabilitas penampilan fenotipik empat varietas unggul ikan nila (Oreochromis niloticus). Jurnal Riset Akuakultur, 10(1):1-2.

Defira, C. N. (2004). Variasi Morfologi, Kariotip dan pola enzim ikan lalawak (Barbodes balleroides) dan lalawak jengkol (Barbodes sp.) dari Sungai Cikandung dan kolam budidaya Desa Buah Dua Kabupaten Sumedang. Tesis. Bogor: Program Pasca Sarjana. Institut Pertanian Bogor.

Dinas Kelautan dan Perikanan Propinsi Jawa Timur-Balai Pengembangan Budidaya Air Tawar Umbulan. (2016). UPT Pengembangan Budidaya Air Tawar Umbulan Kembangkan Nila Unggul Jatimbulan. http://pbatumbulan.co.id. 12/12/2016.

Dunham, R. A. (2004). Aquaculture and fisheries biotechnologi, genetic approaches. Auburn: University. Alabama.

Eldridge, FE. (1985). Cytogenetic of livestock. America: The Avi Publishing Company, Inc.
Hartono, D. P. (2003). Karakteristik kromosom ikan kerapu. Tesis. Bogor: Program Pasca Sarjana. Institut Pertanian Bogor.

Levan, A., Fredga, K., \& Sandberg, A.A. (1964). nomenclature for centromic position on chromosome. Hereditas, 52: 201-220.

Moynihan, E.P. \& Mahon, G.A.T. (1982). Quantitative karyotipe analysis in the mussel Mytilus edulis L. New York. . p. $301-309$.

McGregor, H. C., \& Varley, J. M. (1983). Working with animal chromosome. New York: Jhon Wiley and Son.

Nuryanto, A. (2001). Morfologi, Kariotip dan pola protein ikan nilem (Osteochilus sp.) dari Sungai Cikawung dan kolam budidaya Kabupaten Cilacap. Tesis. Bogor: Program Pasca Sarjana. Institut Pertanian Bogor.

Saputra, W. A., Muslim \& Sasanti, A.D. (2014). Perbedaan jumlah kromosom ikan gabus (Channa Striata) dari rawa dataran rendah, dataran tinggi dan pasang surut. Jurnal Akuakultur Rawa Indonesia, 2(1):67-77.

Siagian, W. K. (2006). Karakteristik kromosom ikan manvis (Pterophyllum scalare). Thesis. Bogor: Program Pasca Sarjana. Institut Pertanian Bogor.

Sofy, H. I., Layla, A.M. \& Iman, M.K.A. (2008). Karyotype diversity of some tilapia species. Nature and Science, 6(1):19-27. 